\section{PENGGUNAAN MICROSOFT EXCEL DALAM PENYUSUNAN LAPORAN KEUANGAN UNTUK MENINGKATKAN KUALITAS INFORMASI LAPORAN KEUANGAN}

\author{
Triandi dan Marina Agustin \\ Program Studi Akuntansi, Sekolah Tinggi Ilmu Ekonomi Kesatuan \\ Bogor, Indonesia \\ Email : lemlit@stiekesatuan.ac.id
}

Microsoft Excel and financial

report

035

Submitted JANUARI 2016

Accepted: FEBRUARI 2016

Compiling a financial reportis important because through this statement both external and internal parties may acquire informations about the firm's financial conditions and its performance. These informations can then be used to make managerial decision for the sake of the firm's future. Building an accounting program corresponding to the company's specific needs can be very expensive and time consuming, not to mention the trials and errors along the way. It takes great efforts to finally come up with ideal accounting program. To solve this issue, Microsoft Excel application provides affordable, simple, fast and accountable accounting program. The aim of this research are to investigate a proper qualitative characteristics of a financial report, to maximize the function of Microsoft Excel application in smaller firms for the purpose of providing a financial statement. The results show that Excel can enchance the informations contained in CV Inovasi Infinita's financial statements. This application helps with its fast, accurate, complete, user friendly and details. Thus the owner can easily analyse each transaction on the daily basis. The application helps contributing in providing better financial reports.

Key words : Microsoft Excel and financial report.

\title{
PENDAHULUAN
}

Saat ini kemajuan teknologi terus berkembang seiring dengan kebutuhan perusahaan dalam melakukan efisiensi yang mulai menerapkan seluruh kegiatan dilakukan dengan menggunakan sistem secara komputerisasi. Kebutuhan tersebut mencakup pada kebutuhan dalam menyusun suatu laporan keuangan dimana laporan keuangan mulai disusun dengan menggunakan sistem teknologi sehingga pencatatan akuntansi didalam suatu perusahaan dilakukan dengan menggunakan komputer. Hal tersebut menjadikan pekerjaan akuntansi menjadi lebih mudah dan cepat sehingga dapat meminimalisir kesalahan dalam penyusunan laporan keuangan.

Penyusunan laporan keuangan ini sangat penting karena melalui laporan keuangan, kondisi keuangan dan kinerja keuangan dapat dilihat sebagai informasi baik bagi pihak internal maupun bagi pihak eksternal. Infromasi keuangan sangat diperlukan khususnya pada saat mengambil keputusan bagi masa depan perusahaan. Melihat hal tersebut, para pembuat aplikasi computer mulai memperkenalkan aplikasi-aplikasi yang berbasis komputer akuntansi seperti Daceasy Accounting, $M Y O B$ Accounting, Peachtree accounting, dan program sejenis lainnya yang mulai membanjiri pasaran tak terkecuali di Indonesia. Namun, kondisi bisnis di Indonesia aplikasi-aplikasi tersebut dirasa kurang cocok karena terkendala keterbatasan jumlah digit pada aplikasi-aplikasi tersebut dan juga biaya pembelian aplikasi serta pemeliharaan aplikasi yang tidak murah.

\section{JIAKES}

$$
\begin{array}{r}
\text { Jurnal Ilmiah Akuntansi } \\
\text { Kesatuan } \\
\text { Vol. } 4 \text { No. } 1,2016 \\
\text { pg. } 035-047 \\
\text { STIE Kesatuan } \\
\text { ISSN 2337-7852 }
\end{array}
$$


Microsoft Excel and financial report
Beberapa perusahaan sebagian besar tidak menggunakan aplikasi namun perusahaan-perusahaan tersebut menggunakan program dalam komputer yang dianggap dapat memenuhi kebutuhan akuntansi dan tidak menghabiskan biaya yang tinggi yaitu dengan menggunakan Microsoft Excel pada aplikasi yang sudah ada dalam komputer.

\section{MAKSUD DAN TUJUAN}

1. Untuk mengetahui bagaimana sistem akuntansi dan proses pembukuan pda CV Inovasi Infinita.

2. Untuk mengetahui bagaimana penggunaan Microsoft Excel dalam Proses akuntansi CV Inovasi Infinita.

3. Untuk mengetahui bagaimana peranan Microsoft Excel dalam meningkatkan kualitas informasi Laporan Keuangan pada CV Inovasi Infinita.

\section{TINJAUAN PUSTAKA}

Menurut Adi Laksono (2006, 2) dalam bukunya 7 Jam Belajar Interaktif Excel 2003 untuk orang Awam, menyatakan bahwa "Microsoft Excel adalah program pengelolaan lembar kerja atau Spreadsheet yang paling populer dan paling banyak digunakan saat ini.

Dalam hal ini laporan keuangan merupakan sebuah informasi yang berasal dari pengolahan data, yaitu data akuntansi. Maka program Microsoft Excel dapat digunakan menjadi sebuah program aplikasi akuntansi yang tersistematis. Untuk dapat mengoperasikan program tersebut diperlukan pengetahuan yang cukup tentang Microsoft Excel disamping pengetahuan tentang dasar- dasar atau prinsip- prinsip akuntansi.

Menurut IAI dalam buku PSAK No 1 (revisi 2009) dikatakan bahwa Laporan Keuangan adalah suatu penyajian terstruktur dari posisi keuangan dan kinerja keuangan suatu entitas. Tujuan laporan keuangan adalah memberikan informasi mengenai posisi keuangan, kinerja keuangan, dan arus kas entitas yang bermanfaat bagi sebagian besar kalangan pengguna laporan dalam pembuatan keputusan ekonomi. Laporan keuangan juga menunjukan hasil pertanggungjawaban manajemen atas penggunaan sumber daya yang dipercayakan kepada mereka.

\section{METODE PENELITIAN}

Analisa terhadap data penelitian dilakukan dengan menggunakan pendekatan kualitatif. Dimana dalam hal ini teknik analisa yang akan digunakan adalah analisa komparatif kualitatif yaitu penulis membandingkan kesesuaian landasan teoritis yang diperoleh dengan penerapannya dilapangan.

\section{HASIL DAN PEMBAHASAN}

Berikut ini langkah-langkah yang dilakukan dalam membuat aplikasi excel: Langkah pertama kita harus membuka terlebih dahulu program Microsoft Excel dengan cara klik start, Microsoft Excel 


\section{Chart Of Account}

Langkah awal pembuatan aplikasi akuntansi dengan menggunakan microsoft excel adalah merancang kode akun atau rekening. Sebuah daftar akun sebaiknya dibuat seringkas mungkin untuk mengakomodasi kepentingan pencatatan transaksi perusahaan. Setelah program excel terbuka, ganti nama sheet 1 menjadi "COA" dengan cara klik kanan, kemudian pilih rename, lalu ketik "COA" dan enter.

Pada sheet COA ini akan dibuat nama-nama akun dan nomor akun yang digunakan dalam proses pencatatan. Nama akun dan nomor akun yang digunakan akan dipakai terus untuk menjadi acuan dalam proses pencatatan.

Digit pertama: untuk kode kelompok induk rekening dalam akuntansi seperti:

a. 1 untuk kelompok Aktiva

b. 2 untuk kelompok Hutang

c. 3 untuk kelompok Modal

d. 4 untuk kelompok Pendapatan

e. 5 untuk kelompok Harga Pokok

f. 6 untuk kelompok Beban

Digit kedua: untuk kode sub kelompok/detail dalam akuntansi seperti:

a. 1 untuk sub kelompok aktiva lancar

b. 2 untuk sub kelompok aktiva tetap

Digit ketiga dan keempat: untuk nomor urut dari setiap rekening

Dari perkiraan-perkiraan akun diatas terdapat akun-akun yang bersaldo normal debet dan bersaldo normal kredit. Adapun saldo normal dari masing- masing akun adalah sebagai berikut:

a. 1 untuk kelompok aktiva saldo normalnya adalah debit

b. 2 untuk kelompok hutang saldo normalnya adalah kredit

c. 3 untuk kelompok modal saldo normalnya adalah kredit

d. 4 untuk kelompok pendapatan saldo normalnya adalah kredit

e. 5 untuk kelompok harga pokok saldo normalnya adalah debit

f. 6 untuk kelompok beban saldo normalnya adalah debit

Setelah tabel perkiraan akun dibuat, kemudian beri nama kolom sesuai kebutuhan, dengan cara sebagai berikut :

a. Arahkan kursor pada sel A6, lalu ketik "Nomor Akun"

b. Arahkan kursor pada sel B6, lalu ketik "Nama Akun"

c. Arahkan kursor pada sel C6, lalu ketik "Saldo Awal"

d. Arahkan kursor pada sel D6, lalu ketik "Saldo Normal"

\section{Jurnal Umum}

Langkah-langkah yang harus dilakukan adalah arahkan kursor ke sheet 2 lalu klik kanan, rename lalu ketik "JOURNAL". Setelah itu kita membuat format tampilan untuk Jurnal Umum:

a. Arahkan kursor pada sel A6, lalu ketik "Tanggal"

b. Arahkan kursor pada sel B6, lalu ketik "No Bukti"

c. Arahkan kursor pada sel C6, lalu ketik "No Akun"

d. Arahkan kursor pada sel D6, lalu ketik "Nama Akun"

e. Arahkan kursor pada sel E6, lalu ketik "Kode"

f. Arahkan kursor pada sel F6, lalu ketik "Nama Customer/ Supplier"

g. Arahkan kursor pada sel G6, lalu ketik "Keterangan"

h. Arahkan kursor pada sel H6, lalu ketik "Debit"

i. Arahkan kursor pada sel I6, lalu ketik "Kredit"

Sehingga menghasilkan tampilan sebagai berikut:
Microsoft Excel

and financial

report

\section{7}


Microsoft Excel and financial report

038
Proses pencatatan transaksi pada jurnal umum adalah:

1. Mengisi tanggal

Atur format tanggal sesuai dengan yang kita inginkan dengan cara klik kotak huruf A sehingga semua kolom A terblok, klik kanan pilih Format cells, pilih tab number, date, pilih format tanggal yang diinginkan.

2. Mengisi No Bukti

No Bukti di isi secara manual sesuai dengan nomor yang tercantum dalam faktur

3. Mengisi Nomor Akun

Untuk mempermudah pengisian nomor akun, kita buat data validation agar tidak perlu melakukan pengetikan, cukup dengan memilih nomor akun yang diperlukan yang diinginkan. Caranya adalah arahkan kursor pada sel C7, pilih data, validation, pada tabs sttings, validation criteria, allow, pilih list, kemudian kolom source diisi dengan data nomor akun yang telah diblok lalu pilih OK

4. Mengisi Nama Akun

Nama Akun pada sel D7 akan terisi secara otomatis sesuai dengan nomor akun yang kita pilih pada $\mathrm{C} 7$, karena $\mathrm{D} 7$ telah dimasukan formula: $=\mathrm{IF}(\mathrm{C} 7=0 ; "$ "; VLOOKUP $(\mathrm{C} 7 ; \mathrm{COA} ! \$ \mathrm{~A} \$ 6: \$ \mathrm{~B} \$ 32 ; 2 ; \mathrm{FALSE}))$

5. Mengisi Kode

Kode pada sel E7 di isi dengan cara pengisian yang sama pada nomor akun (cara no 3) namun pada kolom source di ganti dengan data kode yang telah diblok.

6. Mengisi nama Customer/Supplier

Pengisian nama customer/supplier pada F7 menggunakan cara pengisian yang sama seperti pengisian nama akun (cara no 4). Dengan Formula sebagai berikut: $=\mathrm{IF}(\mathrm{E} 7=0 ; "$; $\mathrm{VLOOKUP}(\mathrm{E} 7 ; \mathrm{COA}$ !\$F $6: \$ G \$ 12 ; 2 ; \mathrm{FALSE}))$

7. Mengisi Keterangan

Pengisian keterangan G7 sesuai dengan keterangan transaksi tersebut.

8. Mengisi Kolom Debit

Kolom Debit H7 di isi dengan nilai rupiah transaksi yang terjadi.

9. Mengisi Kolom Kredit

Kolom Kredit I7 di isi dengan nilai rupiah transaksi yang terjadi.

\section{Buku Besar}

Langkah-langkah pertama untuk membuat buku besar ini adalah ganti nama sheet 3 menjadi GL. Setelah itu buat form buku besar sebagai berikut:

Proses pencatatan buku besar adalah sebagai berikut :

1. Mengisi No akun

Buat data validation untuk sel ini, caranya sama dengan sebelumnya arahkan kursor pada sel B6, pilih data, validation, pada tabs sttings, validation criteria, allow, pilih list, kemudian kolom source diisi dengan data nomor akun yang telah diblok lalu pilih OK

2. Mengisi nama akun

a. Arahkan kursor pada sel B7

b. Masukan Formula $=\mathrm{IF}(\mathrm{B} 6=0 ; "$ "' $\mathrm{VLOOKUP}(\mathrm{B} 6 ; \mathrm{COA} ! \$ \mathrm{~A} \$ 6: \$ \mathrm{~B} \$ 32 ; 2 ; \mathrm{FALSE}))$

Tanda \$ dalam formula didapat dengan menekan tombol f4 pada keyboard setelah memasukan kolom nomor akun dan nama akun. Fungsi formula ini adalah untuk mengisi nama akun secara otomatis sesuai dengan nomor akun dipilih.

3. Mengisi Saldo Awal

a. Arahkan kursor sel F6

b. Masukkan Formula

$=\mathrm{IF}(\mathrm{B} 6=0 ; "$ ";VLOOKUP(B6;COA! \$A $\$ 6: \$ C \$ 32 ; 3 ; \mathrm{FALSE}))$ 
Formula ini dimasukan agar pada sel F6 menampilkan jumlah saldo awal secara otomatis sesuai dengan yang ada di sheet COA kolom ke 3 .

4. Mengisi Saldo Normal

a. Arahkan kursor pada sel F7

b. Masukanformula =IF(B6=0;"';VLOOKUP(B6;COA!\$A \$ $\$$ D \$32;4;FALSE)

Formula ini berguna untuk menampilkan secara otomatis saldo normal yang ada di sheet COA kolom ke 4.

5. Mengisi Tanggal

a. Arahkan kursor pada sel A11

b. Masukan Formula =IF(\$B\$6=JOURNAL!C7;JOURNAL!A7;"')

Penulisan tanggal perlu diperhatikan sesuai dengan format tanggal yang sudah dilakukan dengan cara format, cells, date.

6. Mengisi No Bukti

a. Arahkan kursor pada sel B11

b. Masukan Formula =IF(\$B\$6=JOURNAL!C7;JOURNAL!B7;"')

Formula ini dapat diartikan bila sel B6 sama dengan sel C7 pada sheet Journal maka pada B6 akan terisi no bukti sama dengan yang tercantum C7 pada sheet Journal.

7. Mengisi Keterangan

a. Arahkan kursor pada C11

b. Masukan Formula =IF(\$B \$6=JOURNAL!C7;JOURNAL!G7;"")

Dengan formula ini, keterangan akan terisi secara otomatis apabila Tanggal dan No bukti telah terisi.

8. Mengisi Saldo Awal Debet

a. Arahkan kursor pada sel D10

b. Masukkan Formula $=\mathrm{IF}(" \mathrm{debit}=\$ \mathrm{~F} \$ 7 ; \$ \mathrm{~F} \$ 6 ; 0)$

Dari formula diatas diartikan jika kata "debit" = F7 maka kolom debit berisikan nominal yang sama seperti kolom F6 yaitu saldo awal.

9. Mengisi Saldo Awal Kredit

a. Arahkan kursor pada sel E10

b. Masukkan Formula $=\mathrm{IF}(" k r e d i t "=\$ F \$ 7 ; \$ F \$ 6 ; 0)$

Dari formula diatas diartikan jika kata "kredit" = F7 maka kolom kredit berisikan nominal yang sama seperti kolom F6 yaitu saldo awal.

10. Mengisi Saldo

a. Arahkan kursor F10

b. Masukan Formula $=\mathrm{IF}("$ debit"=\$F\$7;D10-E10;E10-D10)

Formula ini dibaca, jika sel F10 sama dengan F7 maka sel

11. Mengisi Kolom Debet

a. Arahkan kursor pada D11

b. Masukan formula $=\mathrm{IF}(\$ \mathrm{~B} \$ 6=\mathrm{JOURNAL!C7;JOURNAL!H7;0)}$

Dari formula diatas dapat diartikan jika kolom B6 sama dengan kolom C7 pada sheet journal maka kolom D11 akan terisi angka yang sama dengan kolom $\mathrm{H} 7$ pada sheet journal bila berbeda maka akan terisi nol.

\section{Mengisi Kolom Kredit}

a. Arahkan kursor pada E11

b. Masukan formula $=\mathrm{IF}(\$ B \$ 6=J O U R N A L ! C 7 ; J O U R N A L ! I 7 ; 0)$

Dari formula diatas dapat diartikan jika kolom B6 sama dengan kolom C7 pada sheet journal maka kolom E11 akan terisi angka yang sama dengan kolom I7 pada sheet journal bila berbeda maka akan terisi nol.
Microsoft Excel and financial report

$\underline{039}$ 
Microsoft Excel and financial report

040
13. Mengisi Kolom Saldo

a. Arahkan kursor pada F11

b. $\quad$ Masukan Formula $=\mathrm{IF}("$ debit"=\$F\$7;F10+D11-E11;F10+E11-D11)

c. Dari formula diatas dapat diartikan jika sel F7 berisikan saldo normal "debit" maka kolom F11 akan terisikan hasil dari F10+D11-E11 dan jika bukan maka akan terisikan hasil dari rumus F10+E11-D11.

Setelah selesai mengisi semua tabel, kita membuat autofilter dengan cara blok semua judul kolom lalu klik data,filter pada menu bar, sehingga terdapat segitiga hitam kecil di samping masing-masing judul kolom. Autofilter digunakan untuk menyaring atau menyeleksi data yang kita butuhkan saja tanpa harus menghapus data yang lainnya yang terdapat di tabel yang sama cukup dengan menekan tombol panah kecil yang terdapat di kolom tersebut kemudian membuat mark sesuai yang kita inginkan.

\section{Buku Pembantu}

Untuk membuat buku pembantu maka kita membuat sheet baru kemudian mengganti nama sheet menjadi buku pembantu dengan cara klik kanan, rename, lalu ketik buku pembantu kemudian enter.

Proses pencatatan sebagai berikut:

1. Mengisi Kode

Buat data validation untuk sel ini, caranya sama dengan sebelumnya arahkan kursor pada sel B6, pilih data, validation, pada tabs settings, validation criteria, allow, pilih list, kemudian kolom source diisi dengan data kode customer/supplier yang telah diblok lalu pilih $\mathrm{OK}$

2. Mengisi nama customer/supplier

a. Arahkan kursor pada sel B7

b. Masukan Formula

$=\mathrm{IF}(\mathrm{B} 6=0 ; "$ "; VLOOKUP(B6;COA! \$F 6 :\$G $\$ 12 ; 2 ; \mathrm{FALSE}))$

Tanda \$ dalam formula didapat dengan menekan tombol f4 pada keyboard setelah memasukan kolom kode dan nama customer/supplier. Fungsi formula ini adalah untuk mengisi nama customer/supplier secara otomatis sesuai dengan kode yang dipilih.

3. Mengisi Saldo Awal

a. Arahkan kursor sel F6

b. Masukkan Formula $=\mathrm{IF}(\mathrm{B} 6=0 ; "$ ";VLOOKUP(B6;COA! \$F 6 :\$H $\$ 12 ; 3 ; \mathrm{FALSE}))$

Formula ini dimasukan agar pada sel F6 menampilkan jumlah saldo awal secara otomatis sesuai dengan yang ada di tabel daftar buku pembantu.

4. Mengisi Saldo Normal

a. Arahkan kursor pada sel F7

b. Masukan formula =IF(B6=0;"';VLOOKUP(B6;COA!\$F 6 :\$I $\$ 12 ; 4 ; F A L S E))$

5. Mengisi Tanggal

a. Arahkan kursor pada sel A11

b. Masukan Formula =IF(\$B\$6=JOURNAL!E7;JOURNAL!A7;"')

Penulisan tanggal perlu diperhatikan sesuai dengan format tanggal yang sudah dilakukan dengan cara format, cells, date.

6. Mengisi No Bukti

a. Arahkan kursor pada sel B11

b. Masukan Formula =IF(\$B\$6=JOURNAL!E8;JOURNAL!B8;"") 
Formula ini dapat diartikan bila sel B6 sama dengan sel E8 pada sheet Journal maka pada B6 akan terisi no bukti sama dengan yang tercantum B8 pada sheet Journal.

7. Mengisi Keterangan

a. Arahkan kursor pada C11

b. Masukan Formula =IF(\$B\$6=JOURNAL!E7;JOURNAL!G7;"')

Dengan formula ini, keterangan akan terisi secara otomatis apabila tanggal dan no bukti telah terisi.

8. Mengisi Saldo Awal Debet

a. Arahkan kursor pada sel D10

b. Masukkan Formula $=\mathrm{IF}(" \mathrm{debit} "=\$ \mathrm{~F} \$ 7 ; \$ F \$ 6 ; 0)$

Dari formula diatas diartikan jika kata "debit" = F7 maka kolom debit berisikan nominal yang sama seperti kolom F6 yaitu saldo awal.

9. Mengisi Saldo Awal Kredit

a. Arahkan kursor pada sel E10

b. Masukkan Formula $=\mathrm{IF}(" \mathrm{kredit} "=\$ F \$ 7 ; \$ F \$ 6 ; 0)$

Dari formula diatas diartikan jika kata "kredit" = F7 maka kolom kredit berisikan nominal yang sama seperti kolom F6 yaitu saldo awal.

10. Mengisi Saldo

a. Arahkan kursor F10

b. $\quad$ Masukan Formula $=\mathrm{IF}("$ debit"=\$F\$7;D10-E10;E10-D10)

Formula ini dibaca, jika sel F10 sama dengan F7 maka sel D10 dikurangi sel E10, jika tidak sel E10 dikurangi sel D10.

11. Mengisi Kolom Debit

a. Arahkan kursor pada D11

b. Masukan formula =IF(\$B \$6=JOURNAL!E7;JOURNAL!H7;0)

Dari formula diatas dapat diartikan jika kolom B6 sama dengan kolom E7 pada sheet journal maka kolom D11 akan terisi angka yang sama dengan kolom $\mathrm{H} 7$ pada sheet journal bila berbeda maka akan terisi nol.

12. Mengisi Kolom Kredit

a. Arahkan kursor pada E11

b. Masukan formula $=\mathrm{IF}(\$ B \$ 6=J O U R N A L ! E 7 ; J O U R N A L ! I 7 ; 0)$

Dari formula diatas dapat diartikan jika kolom B6 sama dengan kolom E7 pada sheet journal maka kolom E11 akan terisi angka yang sama dengan kolom I7 pada sheet journal bila berbeda maka akan terisi nol.

\section{Mengisi Kolom Saldo}

a. Arahkan kursor pada F11

b. Masukan Formula $=\mathrm{IF}("$ debit"=\$F\$7;F10+D11-E11;F10+E11-D11) Dari formula diatas dapat diartikan jika sel F7 berisikan saldo normal "debit" maka kolom F11 akan terisikan hasil dari F10+D11-E11 dan jika bukan maka akan terisikan hasil dari rumus F10+E11-D11.

Setelah selesai mengisi semua tabel, kita membuat autofilter dengan cara blok semua judul kolom lalu klik data,filter pada menu bar, sehingga terdapat segitiga hitam kecil di samping masing-masing judul kolom. Autofilter digunakan untuk menyaring atau menyeleksi data yang kita butuhkan saja tanpa harus menghapus data yang lainnya yang terdapat di tabel yang sama cukup dengan menekan tombol panah kecil yang terdapat di kolom tersebut kemudian membuat mark sesuai yang kita inginkan.
Microsoft Excel and financial report

\section{1}


Microsoft Excel and financial report

042

\section{Jurnal Penyesuaian}

Pembuatan tabel jurnal penyesuaian dilakukan dengan langkah-langkah sebagai berikut:

1. Arahkan kursor pada sel A6, lalu ketik "Tanggal"

2. Arahkan kursor pada sel B6, lalu ketik "No Akun"

3. Arahkan kursor pada sel C6, lalu ketik "Nama Akun"

4. Arahkan kursor pada sel D6, lalu ketik "Debit"

5. Arahkan kursor pada sel E6, lalu ketik "Kredit"

Proses Pencatatan transaksi pada jurnal penyesuaian adalah sebagai berikut:

1. Mengisi Tanggal Transaksi

Atur format tanggal sesuai dengan yang kita inginkan dengan cara klik kotak huruf A sehingga semua kolom A terblok, klik kanan pilih Format cells, pilih tab number, date, pilih format tanggal yang diinginkan.

2. Mengisi No Akun

Buat data validation agar tidak perlu melakukan pengetikan, cukup dengan memilih nomor akun yang diperlukan yang diinginkan. Caranya adalah arahkan kursor pada sel B8, pilih data, validation, pada tabs sttings, validation criteria, allow, pilih list, kemudian kolom source diisi dengan data nomor akun yang telah diblok lalu pilih $\mathrm{OK}$

3. Mengisi Nama Akun

Nama Akun pada sel C8 akan terisi secara otomatis sesuai dengan nomor akun yang kita pilih pada $\mathrm{B} 8$, karena $\mathrm{C} 8$ telah dimasukan formula:

$=\mathrm{IF}(\mathrm{B} 8=0 ; "$ "; VLOOKUP(B8;COA! $\$ \mathrm{~A} \$ 6: \$ \mathrm{~B} \$ 32 ; 2 ; \mathrm{FALSE}))$

Dengan formula ini maka sel yang dimaksud yaitu C8 akan terisi nama akun sesuai dengan no akun yang berada di sel B8.

4. Mengisi Kolom Debit

Kolom Debit D8 di isi dengan nilai rupiah transaksi yang terjadi.

5. Mengisi Kolom Kredit

Kolom Kredit E8 di isi dengan nilai rupiah transaksi yang terjadi.

\section{Neraca Lajur}

Pertama kita pindah ke sheet yang baru, kemudian rename sheet menjadi Trial Balance.

Untuk mengisi neraca lajur dilakukan dengan cara sebagai berikut :

1. Mengisi Neraca Saldo kolom Debit

Nilai yang terdapat di kolom neraca saldo didapatkan dengan menggunakan formula sebagai berikut :

$=\mathrm{IF}(" \mathrm{DEBIT}=\mathrm{COA} ! \mathrm{D} 8 ; \mathrm{COA}$ !C8;0)

Formula diatas dapat diartikan jika sel D8 pada sheet COA berisikan "debit" maka sel C8 pada sheet Trial Balance berisikan nominal yang sama seperti pada sheet COA sel C8

2. Mengisi Neraca Saldo kolom Debit

Nilai yang terdapat di kolom neraca saldo didapatkan dengan menggunakan formula sebagai berikut :

$=\mathrm{IF}(" \mathrm{KREDIT} "=\mathrm{COA} ! \mathrm{D} 8 ; \mathrm{COA} ! \mathrm{C} 8 ; 0)$

Kemudian copy formula tersebut hingga keseluruh nama akun. Jumlahkan kolom debit dan kredit dengan formula sebagai berikut :

$=\mathrm{SUM}(\mathrm{C} 8: \mathrm{C} 32)$

3. Kolom Jurnal Umum

Kolom debit di isi dengan formula :

$=$ SUMIF $($ JOURNAL!\$D\$6:\$D\$196;'TRIAL

BALANCE'!B8;JOURNAL!\$H6:\$H \$196)

Keterangan :

a. =SUMIF adalah nama fungsi yang artinya menjumlahkan jika. 
b. JOURNAL!\$D\$6:\$D\$196 adalah nama akun yang terdapat pada jurnal umum lalu tekan F4.

c. 'TRIAL BALANCE'!B8 adalah kolom nama akun yang terdapat pada neraca lajur.

d. JOURNAL!\$H \$6:\$H $\$ 196$ adalah kolom debet yang terdapat pada jurnal umum lalu tekan F4.

Kolom Kredit di isi dengan Formula :

$=$ SUMIF(JOURNAL!\$D\$6:\$D\$196;'TRIAL

BALANCE'!B8;JOURNAL!\$I \$ \$I \$196)

Keterangan hampir sama dengan kolom debit.

4. Kolom Saldo Setelah Jurnal Umum

Kolom Debit di isi dengan formula :

$=\mathrm{IF}(\mathrm{C} 8-\mathrm{D} 8+\mathrm{E} 8-\mathrm{F} 8>0 ; \mathrm{C} 8-\mathrm{D} 8+\mathrm{E} 8-\mathrm{F} 8 ; 0)$

Keterangan :

a. =IF adalah nama fungsi yang artinya jika.

b. C8-D8+E8-F8>0 adalah saldo normal di debit setelah mutasi lebih dari 0 .

c. C8-D8+E8-F8;0 artinya apabila saldo debit lebih dari nol maka saldo tersebut akan muncul disisi debit neraca saldo setelah jurnal umum, sebaliknya apabila saldo tersebut kurang dari nol maka saldo tersebut tidak akan muncul disisi debit neraca saldo setelah jurnal umum.

Kolom Kredit dapat di isi dengan formula :

$=\mathrm{IF}(\mathrm{F} 8-\mathrm{E} 8+\mathrm{D} 8-\mathrm{C} 8>0 ; \mathrm{F} 8-\mathrm{E} 8+\mathrm{D} 8-\mathrm{C} 8 ; 0)$

Dapat diartikan jika F8-E8+D8-C8>0 adalah saldo normal di kredit setelah mutasi lebih dari nol. F8-E8+D8-C8;0 artinya apabila saldo kredit lebih dari nol maka saldo tersebut akan muncul disisi kredit neraca saldo setelah jurnal umum, sebaliknya apabila saldo tersebut kurang dari nol maka saldo tersebut tidak akan muncul disisi kredit neraca saldo setelah jurnal umum.

5. Kolom Jurnal Penyesuaian

Kolom Debit di isi dengan formula :

$=$ SUMIF(ADJ!\$C \$8:\$C \$21;'TRIAL BALANCE'!B8;ADJ!\$D\$8:\$D \$21)

Kolom Kredit di isi dengan formula :

$=$ SUMIF(ADJ!\$C\$8:\$C\$21;'TRIAL BALANCE'!B8;ADJ!\$E\$8:\$E $\$ 21)$

Formula tersebut diatas masih memiliki pengertian yang sama dengan formula serupa pada kolom sebelumnya.

6. Kolom Neraca Saldo Disesuaikan

Kolom Debit dapat di isi dengan formula :

$=\mathrm{IF}(\mathrm{G} 8-\mathrm{H} 8+\mathrm{I} 8-\mathrm{J} 8>0 ; \mathrm{G} 8-\mathrm{H} 8+\mathrm{I} 8-\mathrm{J} 8 ; 0)$

Pada formula diatas artinya jika G8-H8+I8-J8>0 adalah saldo normal di debit setelah mutasi lebih dari nol. G8-H8+I8-J8;0 artinya apabila saldo debit lebih dari nol maka saldo tersebut akan muncul disisi debit neraca saldo setelah penyesuaian, sebaliknya apabila saldo tersebut kurang dari nol maka saldo tersebut tidak akan muncul disisi debit neraca saldo setelah penyesuaian.

Kolom Kredit dapat di isi dengan formula :

$=\mathrm{IF}(\mathrm{J} 8-\mathrm{I} 8+\mathrm{H} 8-\mathrm{G} 8>0 ; \mathrm{J} 8-\mathrm{I} 8+\mathrm{H} 8-\mathrm{G} 8 ; 0)$

Formula diatas artinya jika J8-I8+H8-G8>0 adalah saldo normal di kredit setelah mutasi lebih dari nol. J8-I8+H8-G8;0 artinya apabila saldo kredit lebih dari nol maka saldo tersebut akan muncul disisi kredit neraca saldo setelah penyesuaian, sebaliknya apabila saldo tersebut kurang dari nol maka saldo tersebut tidak akan muncul disisi kredit neraca saldo setelah penyesuaian. 
Microsoft Excel and financial report

044

\section{Laporan Keuangan}

1. Laporan Laba Rugi

Laporan laba rugi dibuat pada sheet baru kemudian ganti nama sheet dengan IS (Income Statement)

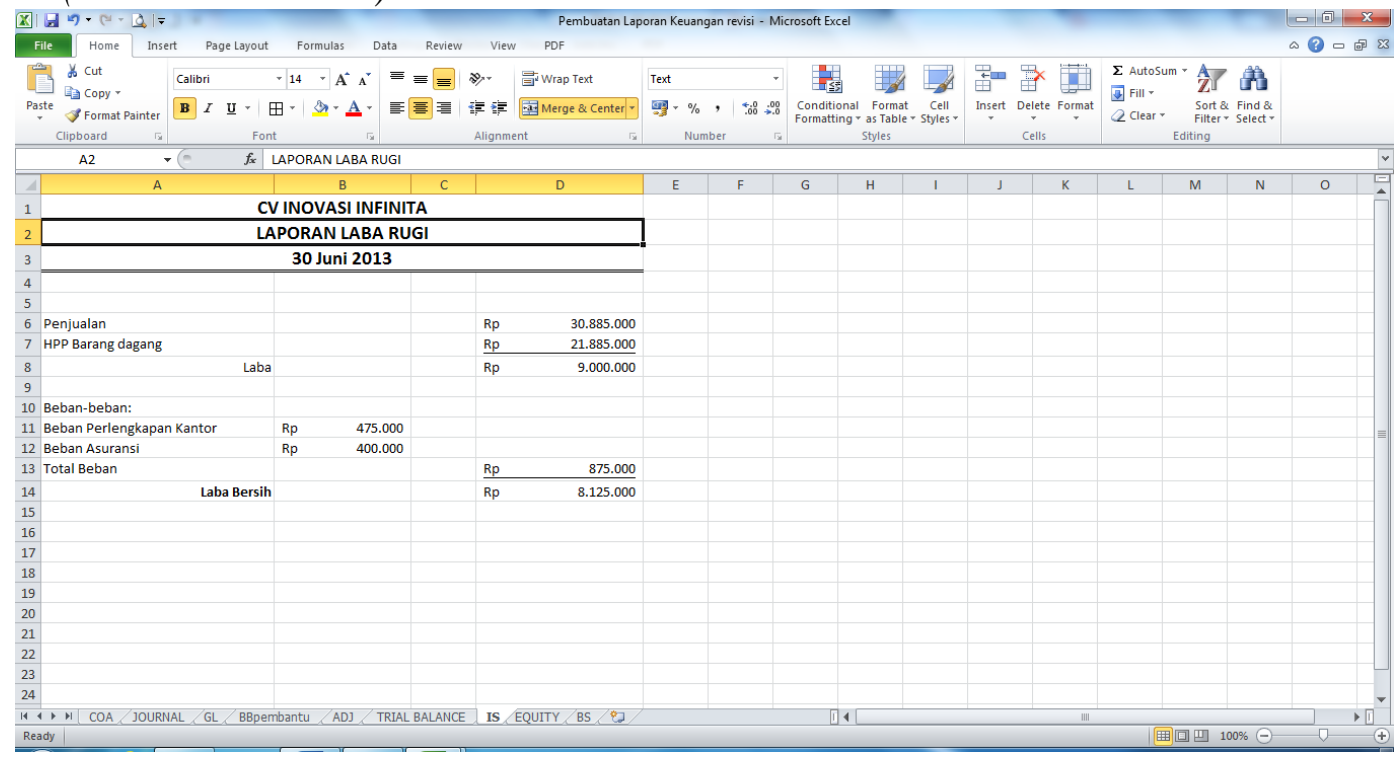

\section{Gambar 1}

Laporan laba rugi

Untuk mengisi saldo penjualan (sel D6) angkanya diambil dari ='TRIAL BALANCE'!L27 artinya saldo penjualan berasal dari sheet neraca lajur pada kolom kredit neraca saldo disesuaikan. Begitu juga selanjutnya dengan akun-akun lainnya yang terdapat dilaporan laba rugi.

\section{Laporan Perubahan Modal}

Laporan perubahan modal dibuat pada sheet baru yang kemudian diganti nama dengan Equity. Laporan perubahan modal dibuat dengan form sebagai berikut :

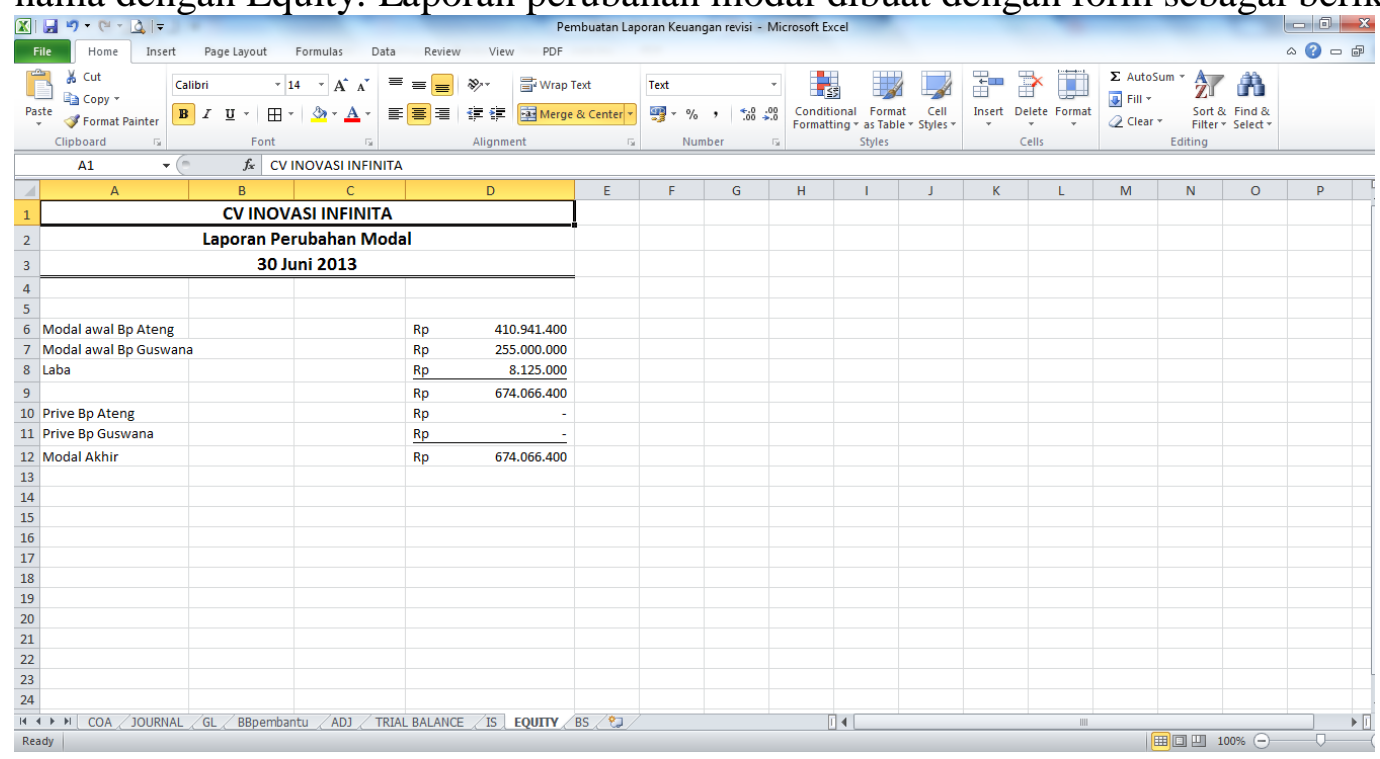

Gambar 2

Laporan Perubahan Modal

Nominal yang tersaji dalam laporan laba rugi tersebut diperoleh dari :

a. Modal Awal

Menggunakan formula sebagai berikut :

$=$ 'TRIAL BALANCE'!L23

Nilai modal awal diambil dari nilai yang terdapat dalam neraca saldo disesuaikan.

b. Laba 
=IS!D18 artinya laba berasal dari sheet laba rugi pada kolom laba bersih.

c. Modal Akhir

Diperoleh dari hasil penjumlahan modal awal dengan laba dikurangi prive.

3. Neraca

Neraca dibuat pada sheet baru kemudian ganti nama dengan BS (Balance Sheet). Saldo yang terdapat di neraca, diperoleh hasilnya dari neraca saldo setelah disesuaikan. Dengan contoh sebagai berikut :

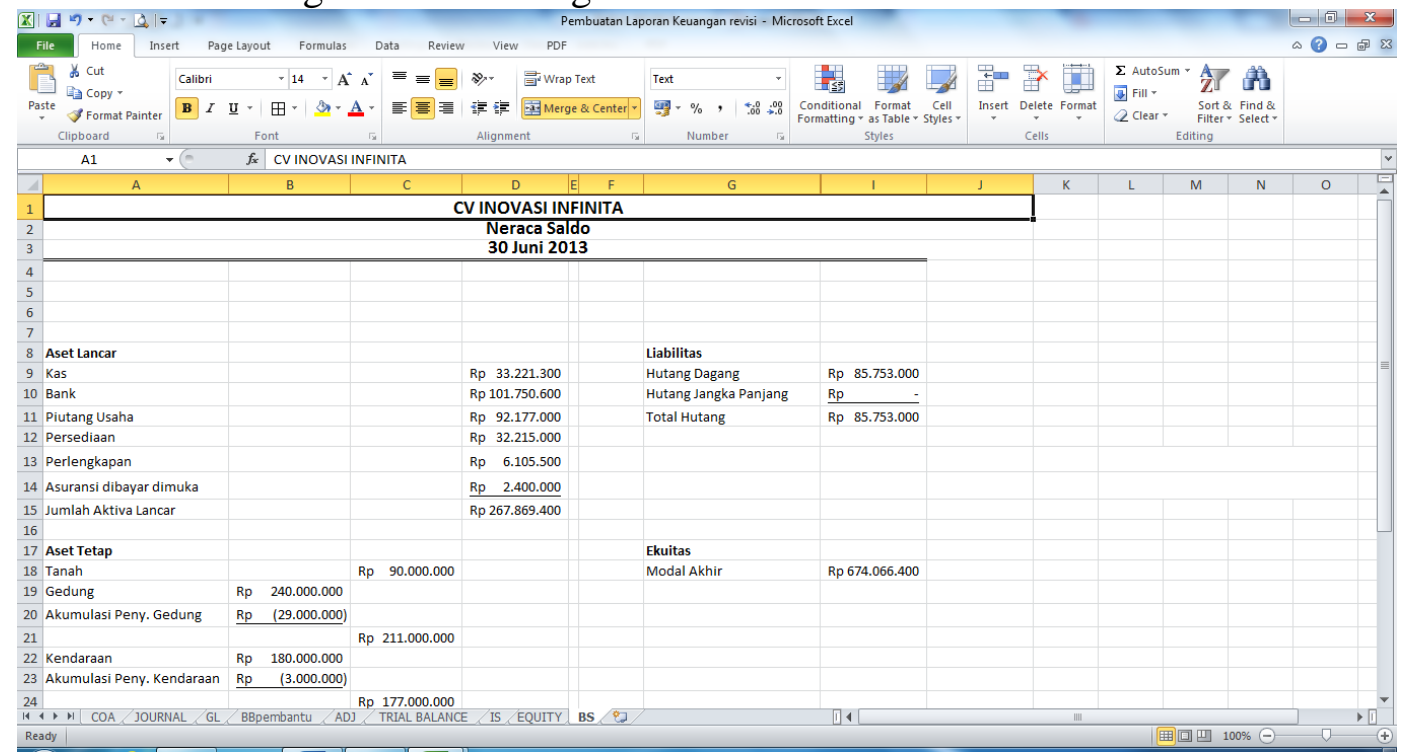

Gambar 4.41

Neraca

Saldo kas diperoleh dengan menggunakan formula ='TRIAL BALANCE!K8 maka dapat diartikan bahwa saldo kas tersebut didapat dari sheet trial balance yang terdapat di sel K8.

Dengan menerapkan Microsoft Excel sebagai sistem akuntansi dalam perusahaan membuat pekerjaan lebih mudah bagi para pegawai administrasi di CV Inovasi Infinita. Microsoft Excel lebih mudah dipahami, karena kualitas di dalam Microsoft Excel memiliki sistem yang tepat dan saling berkaitan. Setiap transaksi dapat dibukukan secara rapi, cepat, akurat. Selain itu juga tentunya dengan menerapkan sistem ini dapat meminimalkan terjadinya kesalahan dan setiap terjadi kesalahan dapat diketahui dengan cepat.

Microsoft Excel mengolah data laporan keuangan CV Inovasi Infinita menjadi tepat waktu, perbedaan yang cukup besar antara sistem akuntasi manual dengan sistem Microsoft Excel ini adalah penyajian laporan keuangan tersebut yang cepat. Rancangan sistem yang tepat selain menghasilkan laporan keuangan juga menghasilkan kecepatan dalam menyajikan laporan keuangan.

Dengan Microsoft Excel penyajian laporan keuangan dapat diuji kebenarannya oleh pengukur yang independen dengan menggunakan metode pengukuran yang subjektif guna meningkatkan manfaat informasi keuangan.

Selain mudah dipahami dan tepat waktu dalam penyajjian laporan keuangan kesimpulan akhir dalam sistem akuntansi Microsoft Excel adalah efisiensi yang dihasilkan, hal ini dikarenakan biaya yang diperlukan untuk mendapatkan prangkat lunak Microsoft Excel tidak terlalu besar lain halnya dengan program yang sudah terkenal yang ditawarkan dengan harga yang cukup tinggi di pasaran.

Keuntungan lainnya menggunakan Microsoft Excel adalah kita dapat mengetahui riwayat transaksi dengan mudah. Melalui media buku besar, transaksi yang tercatat pada setiap akun-akun dapat kita telusuri dengan mudah. Begitu banyak keuntungan yang dapat kita peroleh hanya dengan menggunakan program sederhana yaitu Microsoft Excel. Dengan memaksimalkan fungsi-fungsi yang terdapat dalam Microsoft Excel maka CV Inovasi Infinita dapat mengarah ke arah pelaporan
Microsoft Excel and financial report

045 
Microsoft Excel and financial report

046 keuangan yang sesuai dengan standar pelaporan yang berlaku di Indonesia. Dan program ini dapat menghasilkan buku pembantu yang tentunya sangat membantu CV Inovasi Infinita dalam mengontrol hutang dan piutang setiap customer dan supplier.

Akan tetapi masih terdapat keterbatasan dalam program Microsoft Excel ini yaitu :

1. Dengan begitu banyak data transaksi yang diinput maka Excel akan menjadi lebih lambat dari pada menggunakan program komputer yang berbasis "database"

2. Untuk menyusun laporan keuangan periode berikutnya maka harus memasukkan saldo awal kembali dengan rumus yang baru.

3. Program ini dibuat untuk mengarahkan CV Inovasi Infinita untuk membuat laporan keuangan yang sesuai standar namun tidak dibuat hingga proses closing.

Dengan kelebihan yang ada peranan program Microsoft Excel ini sangat membantu CV Inovasi Infinita dalam masalah pencatatan transaksi dan masalah hutang piutang sehingga dapat bekerja lebih cepat, tepat dan tentunya dapat menghasilkan informasi yang akurat sesuai standar pelaporan akuntansi yang memadai yaitu dapat menghasilkan laporan neraca, laporan laba rugi, dan laporan perubahan ekuitas.

\section{SIMPULAN}

1. CV Inovasi Infinita masih menggunakan sistem akuntansi manual yang sederhana dalam sistem akuntansinya, dimana setiap transaksi yang terjadi setiap harinya dicatat dan direkap per minggunya. CV Inovasi Infinita belum memiliki sistem pembukuan yang memadai yang dapat menghasilkan laporan keuangan sesuai standar laporan keuangan yang berlaku.

2. Dalam sistem ini CV Inovasi infinita tidak menyelenggarakan buku hutang dan piutang, hanya menyimpan bukti-bukti transaksi pembelian barang dagangan dan penjualan. Atas dasar bukti-bukti tersebut, CV Inovasi Infinita menerima pembayaran piutang dan membayar hutang. Karena perusahaan tidak menghasilkan laporan neraca, maka perusahaan tidak dapat mengetahui bagaimana kinerja perusahaan selama ini. Pemilik modal juga sulit memperkirakan kondisi keuangan CV Inovasi Infinita tersebut.

3. Untuk itu penulis mencoba memaksimalkan fungsi-fungsi yang ada dalam Microsoft Excel agar dapat membuat suatu sistem yang terkomputerisasi seperti halnya yang menggunakan program-program akuntansi yang ada. Dengan menggunakan Microsoft Excel ini dapat membantu perusahaan dalam mencatat setiap transaksi cukup dengan input jurnal selanjutnya semua proses hingga pelaporan dapat dilakukan dengan secara otomatis karena sistem yang berkaitan. Penerapan sistem ini juga menghasilkan laporan yang hampir sesuai dengan standar dengan adanya laporan laba rugi, laporan perubahan modal dan neraca.

4. Penerapan Microsoft Excel informasi yang dihasilkan lebih akurat, tingkat kesalahan yang terjadi menjadi lebih kecil dan proses pengolahan informasi menjadi lebih cepat. Penggunaan Microsoft Excel dalam penyajian laporan keuangan yang tepat waktu tentunya dapat memberikan pertanggung jawaban yang lebih berguna kepada pemilik modal atas kinerja perusahaannya selama periode tertentu. 


\section{DAFTAR PUSTAKA}

Adi laksono. 2006. 7 Jam Belajar Interaktif Excel 2003 untuk Orang Awam. CV Maxikom.

Al. Haryono Jusup. 2003. Dasar-Dasar Akuntansi, jilid 2. Edisi 6, Penerbitan Sekolah Tinggi Ilmu Ekonomi YKPN, Yogyakarta.

Carl s. Warren, James M. Reeve, Philip E.Fess. 2005, Accounting 21 ${ }^{e}$, Penerbit Thomson South-Western.

Donald E. Kieso, Jerry J. Weygant \& Terry D. Warfield. 2011. Intermediate Accounting:IFRS Edition, Volume 1, John Wiley \& Sons,Inc

Hadri Mulya. 2008. Memahami Akuntansi Dasar. Edisi 2. Penerbit Mitra Wacana Media.

Harahap, Sofyan Syafri. 2002. Teori Akuntansi Laporan Keuangan. Bumi Aksara, Jakarta.

Ikatan Akuntan Indonesia. 2004. Standar Akuntansi Keuangan. Penerbit Salemba Empat, Jakarta.

James D. Stice, Earl K.Stice, K.Fred Skousen. 2009. Intermediate Accounting jilid 1. Penerbit Salemba Empat, Jakarta.

Johar Arifin dan Busono Adi Wicaksono. 2006. Komputer Akuntansi Dengan Microsoft Excel. Penerbit PT. Elex Media Komputindo, Jakarta.

Marshall, David H., Wayne W. McManus, Daniel F. Viele, 2007, Accounting, Seventh Edition, Penerbit Mc Graw-Hill Irwin.

Niswonger, C. Rollin, Carl S. Warren, James M. Reeve, dan Philip E. Fees, 2005, Prinsip-prinsip Akuntansi Jilid 1. Edisi 21, penerjemah; Alfonsius sirait, Helda Gunawan, Relangga, Jakarta.

Soemarso SR. 2004. Revisi Akuntansi Suatu Pengantar, Buku 1, Edisi 5. Salemba Empat, Jakarta.

Suharli, Michell. 2006. Akuntansi untuk Bisnis Jasa dan Dagang. Edisi 1. Graha Ilmu, Yoyakarta.

Sutabri, Tata. 2004. Sistem Informasi Akuntansi. Yogyakarta: ANDI

Sutrisno. 2006. Akuntansi Proses Penyusunan Laporan Keuangan. Penerbit Ekonisia, Yogyakarta.

Syarifuddin. 2004. Program Aplikasi Akuntansi dengan Microsoft Excel. Qowamedia Utama, Solo.

Taufik Hidayat. 2009. Teori dan Praktik Membuat Aplikasi Dengan Ms. Excel. Cetakan pertama. Penerbit Mediakita, Jakarta.

Wikipedia. 2012. Microsoft Excel. Menurut (http: //id.wikipedia.org/wiki/Microsoft Excel) (diakses 2 September 2012)

Wikipedia. 2012. Microsoft Excel. Menurut (http: /ne.wikipedia.org/wiki/Microsoft Excel) (diakses 2 September 2012)

Zaki Baridwan. 2004. “Intermediate Accounting”. Edisi 8, Penerbit BPFE UGM, Yogyakarta.
Microsoft Excel

and financial

report

$\underline{047}$ 
